\title{
Responsabilidade Social e Aspetos Ambientais em Empresas Familiares: Um estudo multicascos no Agronegócio
}

\author{
Lesley Carina do Lago Attadia Galli ${ }^{1}$, Arthur Morgado Janones ${ }^{2}$, André Cavalcante \\ da Silva Batalhão 3 , Rafael Altafin Galli4 \\ ${ }^{1}$ Universidade Estadual Paulista (UNESP) - lesleyattadia@fcav.unesp.br \\ 2 Universidade Estadual Paulista (UNESP) - arthurmjanones@gmail.com \\ 3 Universidade Federal de Goiás (UFG) - andre.ciamb.ufg@gmail.com \\ 4 Universidade Estadual de Minas Gerais (UEMG) - afaelaltafin@hotmail.com
}

\section{PALAVRAS-CHAVE}

Responsabilidade Social,

Desenvolvimento Sustentável,

Stakeholder,

Empresa Familiar.

Recebido 08.10.2018

Revisado 13.03.2019

Aceito 05.04.2019

ISSN 1980-4431

Double blind review

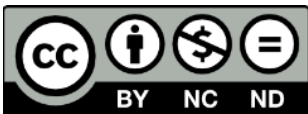

\section{RESUMO}

O conceito de responsabilidade social pode ser definido como a forma de gestão que preza pela relação ética e transparente da empresa com todas as partes interessadas com os quais ela se relaciona. Mesmo que a demanda por ações de cunho sócio- responsável seja evidente, não são todas as organizações que tem capacidade de coloca-las em prática, e quando o assunto são as empresas familiares, esta realidade é a ainda mais distante, visto que muitas destas empresas não sabem como pensar a responsabilidade social estrategicamente. Este trabalho fez um mapeamento das ações de responsabilidade social e iniciativas relacionadas ao meio ambiente, articuladas por empresas familiares atuantes no agronegócio. Foi realizada uma pesquisa aplicada de caráter descritivo e abordagem qualitativa, utilizando como método de pesquisa o estudo multicasos, com oito empresas familiares situadas no interior do estado de São Paulo, Brasil. Os resultados apontaram que a obrigatoriedade legal fomenta grande parte das ações das empresas familiares, em detrimento de ações voluntárias e espontâneas em prol de seus stakeholders.

\section{KEYWORDS}

Social Responsibility, Sustainable Development, Stakeholder, Family Business.

\section{ABSTRACT}

The concept of social responsibility can be defined as the form of management that values the ethical and transparent relationship of the company with all the stakeholders with whom it relates. Even if the demand for socially responsible actions is evident, not all organizations have the capacity to put them into practice, and when it comes to family businesses, this reality is even more distant, since many of these companies do not know how to think about social responsibility strategically. This work mapped the actions of social responsibility and initiatives related to the environment, articulated by family companies working in agribusiness. An applied research of descriptive character and qualitative approach was carried out, using as a research method the multi-case study, with eight family companies located in the interior of the state of São Paulo, Brazil. The results demonstrated out that the legal obligation fosters a large part of the actions of family companies, to the detriment of voluntary and spontaneous actions in favor of their stakeholders. 


\section{Introduction}

A busca pela maximização do lucro no menor período de tempo possível e pelo alcance dos objetivos organizacionais, deixando de lado todo e qualquer aspecto socioambiental, aos poucos, vem se tornando antiquada (BATEMAN; SNELL, 2006) e dando espaço para uma postura corporativa que enfatiza o equilíbrio entre os objetivos econômicos, sociais e ambientais (ZACCARIOTTO et al., 2015).

Até o final dos anos 70, a responsabilidade social corporativa foi ridicularizada e tratada como piada por muitos empresários (LYDENBERG, 2005). Já por volta dos anos 80 , diversos incidentes socioambientais, provocadas por empresas de grande representatividade e abrangência mundial, foram evidenciados na mídia, denegrindo a imagem dessas organizações e fazendo com que a sociedade passasse a cobrar uma nova postura por parte dessas empresas (TEODÓSIO; BARBIERI; CSILLAG, 2006). Diante dessa pressão, muitas organizações perceberam que suas ações deveriam ser imediatamente revistas e começaram a adotar ações de responsabilidade social, a fim de reconquistar sua credibilidade (DIAS, 2012).

No final dos anos 90, o conceito de responsabilidade social ganhou notoriedade mundial, passando a ser estudado pelo meio acadêmico (LEE, 2008). Concomitantemente, as organizações passaram a pautar suas decisões nos princípios da responsabilidade social, balanceando os interesses da sociedade $\mathrm{e}$ os objetivos empresariais (SOUZA; FERREIRA, 2010).

Atualmente, o conceito de responsabilidade social alude a uma organização eticamente governada por meio de uma gestão correta, justa e sustentável, que age em prol da sociedade e de seus stakeholders (DIAS, 2012). A responsabilidade social não deve estar relacionada apenas a ações filantrópicas, mas estar atrelada ao planejamento estratégico organizacional (PEREIRA; FENDRICH, 2009). Complementando esta definição, Gomes et al. (2005) destacam que a responsabilidade social se apresenta como o compromisso que a empresa deve ter perante o ambiente externo, de diversas formas, como, por exemplo, em seu modo de exploração dos recursos ambientais.

Embora haja um esforço por parte de muitas organizações em fomentar a responsabilidade social, observa-se que grande parte das empresas brasileiras acredita que a responsabilidade social só pode ser praticada de maneira efetiva pelas organizações de grande porte (HANDY, 2005). Há empresas que apenas utilizam o conceito de maneira superficial criando, junto à sociedade, uma imagem falsa de organização politicamente correta (COELHO; GOSLING, 2012). Essa mesma visão é compartilhada por inúmeras empresas familiares que não sabem como pensar a responsabilidade social estrategicamente, nem operacionalizar as ações de responsabilidade social junto aos seus stakeholders (SERPA; FOURNEAU, 2007).

Ao direcionar a discussão para o contexto das empresas familiares de micro e pequeno porte, cujo principal objetivo ainda é a sobrevivência perante os concorrentes, a responsabilidade social, tal qual é praticada nas organizações de grande porte, ainda é algo bastante difícil de ser operacionalizado, não só pela escassez de recursos para desenvolver programas consistentes, como também, pela própria miopia de muitos gestores, que ainda não reconhecem a responsabilidade social como fator crítico de sucesso para manutenção da competitividade empresarial (ZACCARIOTTO et al., 2015). É considerada empresa familiar a organização cujo controle societário é exercido por uma família ao longo do tempo, ou seja, os principais sócios da organização são fundadores ou seus descendentes. Assim podese dizer que a empresa familiar tem sua jornada fundamentada na realização do sonho do fundador, que muitas vezes é o pai da família (FLORIANI; RODRIGUES, 2000), refletindo os anseios da família, a partir de uma perspectiva empreendedora (MÜLER; BEUREN, 2010).

Para muitas organizações familiares a responsabilidade social representa "um luxo ao qual elas não podem se dar", sendo o assistencialismo o meio mais simples e menos dispendioso de impactar a sociedade positivamente (GOMES; SANTOS; GOMES, 2005). Além disso, a maior parte das organizações familiares não dispõe, em seu quadro funcional, de especialistas que saibam criar programas de responsabilidade social e liga-los à missão e aos objetivos estratégicos da organização (GONÇALVES; DESIDERIO; GUTIERREZ, 2006).

Dentro deste contexto, faz-se necessário entender em maior profundidade como as empresas familiares vêm articulando as ações de responsabilidade socioambiental, levando em

Revista de Negócios, v. 23, n. 4, p. 47-69, October, 2018. 
conta as limitações em termos de recursos e capacidades, bem como as peculiaridades deste tipo de organização.

A principal contribuição desta pesquisa foi a percepção de quão útil pode ser conhecer e explorar as ações de responsabilidade social, integrando em seu espectro, os aspectos ambientais. Isso pode facilitar a localização de elos conceituais que se revelam no campo empírico de pesquisa, e podem sugerir ferramentas de gestão mais robustas. Este estudo pode impulsionar e apoiar outros níveis de avaliação de empresas familiares, incluindo a administração de mais de uma unidade de negócio, na adoção e exploração de abordagens de desempenho associadas ao setor do agronegócio.

Diante do que foi exposto, este trabalho apresenta a seguinte questão de pesquisa: de que forma as empresas familiares do setor do agronegócio articulam as ações de responsabilidade socioambiental? Tomando como base a questão de pesquisa, o objetivo deste trabalho foi fazer um mapeamento das ações de responsabilidade social articuladas por empresas familiares atuantes no agronegócio junto a seus stakeholders.

\section{Quadro teórico}

2.1 Responsabilidade Social e aspectos socioambientais e os stakeholders

$\mathrm{O}$ atual contexto empresarial tem mostrado que as relações comerciais entre as organizações e seus clientes se tornaram mais complexas e passaram a exigir novos padrões de competitividade. De fato, segundo Thurow (1997), as forças políticas, econômicas e sociais são responsáveis pela criação de um ambiente mercadológico competitivo e volátil, onde produtos e serviços deixaram de ser fatores de diferenciação para uma empresa. Nesse ambiente exigente há uma crise generalizada de valores humanos e ambientais, em que existe uma busca corrente de soluções sustentáveis, que sejam economicamente viáveis e socialmente responsáveis (CARVALHO; VERÍSSIMO, 2018).

$\mathrm{Na}$ verdade, os padrões atuais de competitividade vão além do preço dos produtos, destacando-se entre eles a qualidade e o pós-venda. Essas mudanças drásticas no processo econômico e produtivo mundial, a partir da década de 90 principalmente, têm contribuído para que o ambiente de negócios se mostre cada vez mais turbulento (SANCHES, 2000). É fato que o modelo de crescimento econômico utilizado atualmente vem gerando enormes desequilíbrios sociais e ambientais. Se por um lado nunca houve tanta riqueza e fartura no mundo graças à capacidade de produção de bens e serviços de inúmeras organizações, por outro lado, a miséria, a degradação ambiental e a poluição aumentam diaa-dia (COSTA, 2002).

Ao mesmo tempo observa-se, concomitantemente, o surgimento de diversos movimentos sociais que visam atender aos interesses da sociedade sob a perspectiva de organizações integrarem em sua gestão os aspectos econômicos, sociais e ambientais promovendo o desenvolvimento sustentável (GOMES, 2006). Essa pressão é ainda mais forte, segundo Alves, Raphaelli e Fangueiro, (2006) em setores econômicos cujo produto final pode provocar impactos diretos no equilíbrio dos ecossistemas.

Os pressupostos anteriormente apontados permitem inferir que para enfrentar os desafios atuais, as organizações precisam aprender a administrar os impactos sociais e ambientais de suas ações (SERPA, 2006). A abordagem ambiental das empresas e organizações em geral deve ser internalizada nas estruturas de operação e gestão, vinculando um possível melhoramento de reputação, gestão e inovação corporativa, considerando a preocupação ambiental no seu arcabouço prático. Isso pode ser compilado por instrumentos de gestão de dados, que visam refletir o valor das ações empresariais nos campos social e ambiental (FARINOS, 2015). Isto significa não só prover lucro aos acionistas, mas fundamentalmente, beneficiar os demais stakeholders: colaboradores, sociedade e meio ambiente (CARRIGAN, 1995). Cada vez mais os vários tipos de stakeholders estão mais próximos de diferentes organizações, e das demandas ambientais organizacionais (DOMINGUES et al., 2017).

Buscando definir o termo stakeholder, Freeman (1984) argumenta que se trata de um grupo que afeta ou é afetado pelo atingimento dos objetivos da organização, sem a necessidade de haver reciprocidade entre os agentes. Junto a esta definição, cabe também acrescentar o significado do conceito "saliência de stakeholder", que representa o grau ao qual o gestor dá prioridade às

Revista de Negócios, v. 23, n. 4, p. 47-69, October, 2018. 
demandas dos stakeholders (AGLE et al., 1999). O conceito de "saliência de stakeholder" surge, de acordo com Donaldson e Preston (1995), pela necessidade dos gestores em identificar os diferentes grupos envolvidos com a organização, determinando os interesses específicos de cada um. Também existem stakeholders mais e menos importantes e que, portanto, devem receber distintos graus de atenção. Neste sentido, torna-se importante estabelecer uma hierarquização dos stakeholders, a fim de estabelecer como serão atendidas as demandas de cada um, de acordo com definição dos gestores (BOAVENTURA, 2012).

Centralizando a discussão no eixo social, nota-se que para uma organização conquistar e manter uma imagem positiva perante o mercado, não basta produzir produtos e serviços com qualidade, gerar empregos e pagar seus impostos em dia; ela precisa, além disso, atuar de forma ética, demonstrando consciência no que diz respeito ao tratamento das questões relacionadas aos colaboradores e clientes, e ainda contribuir de forma efetiva com a minimização dos problemas sociais da comunidade (GOMES, 2006).

No setor privado, um dos principais fenômenos contemporâneos é a chamada responsabilidade social empresarial, que inclui no seu escopo a divulgação de informações nãofinanceiras, integrando também, especificamente, questões ambientais, apontando novas abordagens de iniciativas no campo da responsabilidade social (HERNANDEZ et al., 2018). Nesse ínterim o conceito de responsabilidade social empresarial surge para tratar dos aspectos que envolvem a articulação do eixo social do desenvolvimento sustentável (GOMES, 2006). Desde, então, as questões relacionadas ao tema vêm ganhando atenção especial do meio empresarial e gerando diversos debates nas comunidades acadêmicas.

Nota-se preocupação em tentar integrar a responsabilidade social ao planejamento estratégico das organizações (MOTTA; ROSSI, 2001) e em entender como as políticas de responsabilidade social podem ser transformadas em ações e projetos capazes de dar sustentação ao modelo de negócios da organização (GOMES, 2006). Também é notório que as empresas estão cada vez mais incentivadas a integrar questões e demandas sociais nos seus mecanismos de gestão, relacionando-as às atividades lucrativas (DESA, 2017).

\subsection{Empresa Familiar}

Segundo Oliveira (1999), o início das empresas familiares no Brasil se deu com as companhias hereditárias, no início do século XVI, logo após seu descobrimento por Portugal. Essas companhias podiam ser transferidas por herança aos herdeiros dos capitães administradores dessas terras na época. Com o movimento imigratório, houve o incremento de muitas empresas familiares com descendência italiana, japonesa, alemã entre outras, expandindo este modelo empresarial nacionalmente.

Antes de apresentar o conceito de empresas familiares torna-se essencial compreender a noção da família no mundo atual, pois é a partir dos modelos familiares existentes atualmente que pode surgir a noção de empresas familiares (MACHADO, 2005).

As transformações ocorridas na modelo familiar ocidental, com o crescente declínio da família patriarcal vêm causando impactos em empresas familiares. Este declínio, se deu principalmente na década de 1980 com a globalização e a entrada das mulheres no mercado de trabalho. Com isso, atualmente é possível existir uma empresa familiar constituída por uma família mono parental, na qual trabalham, por exemplo, mãe e filha. Apesar disso, muitos estudos continuam sendo desenvolvidos, com o enfoque de empresa familiar e família patriarcal. Nesse sentido, a complexidade do tema se dá tanto pela dificuldade em compreender os novos arranjos familiares, como pela heterogeneidade de modelos de estruturas familiares dentro de uma mesma cultura (MACHADO, 2005).

Há apontamentos na literatura atual demonstram que uma empresa familiar, e controlada por estes, deve ser profissionalizada, de maneira semelhante à empresas não-familiares, incluindo e adequando práticas que possam favorecer a eficiência e sofisticação do negócio (SAMARA; PAUL, 2018).

Neste sentido, é imprescindível destacar que o interesse na internacionalização de pequenas empresas familiares aumentou rapidamente devido a um acentuado dinamismo do processo de globalização na economia mundial (ZAHRA; GEORGE, 2002). Isso também se relaciona diretamente com o mercado do agronegócio brasileiro (MEDINA; SANTOS, 2017). No processo de sofisticação, o crescimento e aderência

Revista de Negócios, v. 23, n. 4, p. 47-69, October, 2018. 
das redes sociais desempenham um papel mediador entre o desempenho da empresa no mercado e sua participação no mercado (ZHOU et al., 2007). As ferramentas virtuais podem gerar agilidade para a articulação empresarial, e, ao mesmo tempo, propiciar auditorias em tempo real de seus resultados, e de todo sua cadeia de negócio (VENKATRAMAN; VENKATRAMAN, 2019). No entanto, o tema "empresas familiares" ainda é pouco explorado por iniciativas internacionais, $\mathrm{o}$ que lança o desafio de entender completamente as empresas familiares em seus contextos particulares, seja por experiências empíricas (CASILLAS; MORENO-MENÉNDEZ, 2014), ou por uma definição conceitual consensual (CHETTY et al., 2014). Também tem sido observado que o envolvimento da família como propriedade indireta, por meio do controle piramidal do negócio, aumenta a rotatividade de executivos, o que sugere a existência de mercados internos para estes profissionais dentro de grupos de negócio (GONZÁLEZ et al., 2019).

\section{Métodos e recursos metodológicos}

A técnica de pesquisa estudo multicaso foi adotada pela presente pesquisa, pois envolve mais de dois sujeitos analisados (MARTINS, 2000; YIN, 2001). A pesquisa possui abordagem predominantemente qualitativa, abrangendo um entendimento específico da relação entre o tema proferido no estudo e o método utilizado (BECKER, 1996). O estudo foi organizado em uma sequência linear de etapas: i) etapas conceituais; ii) etapas metodológicas; e, iii) etapas empíricas, como sugerido por Flick (2001).

Para a consecução do trabalho foi adotado como método de coleta de dados a entrevista semiestruturada (RICHARDSON, 1999), que é a técnica de coleta de dados mais empregada nas pesquisas com empresas familiares, sendo comumente conjugada com a técnica de observação e de análise documental (BORGES; LESCURA, OLIVEIRA 2012). Como método de análise de dados, foi escolhida a análise de conteúdo, que uma técnica que permite ao pesquisador classificar e comparar com maior facilidade as informações obtidas nas entrevistas, facilitando posteriormente a caracterização e análise das variáveis de pesquisa (AAKER; KUMAR; DAY, 2004). Esta é a técnica de análise mais difundida nas pesquisas sobre empresas familiares no Brasil, sobretudo devido a sua praticidade e difusão entre os pesquisadores, e à utilização de uma abordagem qualitativa de investigação (BORGES; LESCURA, 2010). O instrumento de pesquisa, se trata de um instrumento adaptado, cujas alternativas de resposta vão de 1 ("discordo plenamente") a 5 ("concordo plenamente") e o preenchimento deste por parte do próprio entrevistador tem o intuito de evitar o viés que poderia existir caso o mesmo fosse preenchido pelo entrevistado.

\subsection{Estruturação da abordagem metodológica para coleta e análise dos dados empíricos}

Na Tabela 1 estão descritas a Dimensão e as Categorias de Análise incluídas no instrumento de coleta de dados, e suas respectivas referências bibliográficas que suportam cada questão proposta e analisada pelo estudo.

Tabela 1. Descrição e identificação das categorias de análise e a abordagem conceitual, baseado no referencial de cada questão aplicada na pesquisa

\begin{tabular}{|c|c|c|c|}
\hline Dimensão & Categorias & $\begin{array}{l}\text { Conteúdo sintetizado } \\
\text { das questões }\end{array}$ & $\begin{array}{l}\text { Quantidade } \\
\text { de questões }\end{array}$ \\
\hline \multirow{4}{*}{ 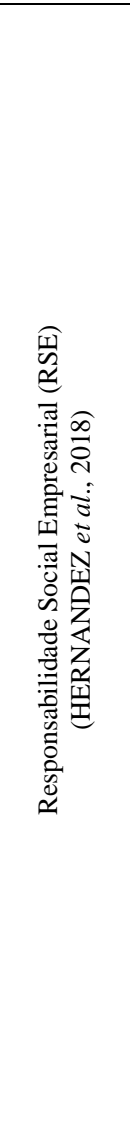 } & $\begin{array}{c}\text { Desenvolvim } \\
\text { ento em } \\
\text { relação à RSE } \\
\text { (DIAS, 2012; } \\
\text { COELHO; } \\
\text { GOSLING, } \\
\text { 2012) } \\
\end{array}$ & $\begin{array}{c}\text { Qual o nível de } \\
\text { desenvolvimento em } \\
\text { relação à RSE, } \\
\text { considerando Obrigação } \\
\text { Social, Reação Social, e } \\
\text { Sensibilidade Social? }\end{array}$ & 3 \\
\hline & $\begin{array}{l}\text { Alinhamento } \\
\text { estratégico } \\
\text { em relação à } \\
\text { RSE } \\
\text { (MOTTA \& } \\
\text { ROSSI, 2001) }\end{array}$ & $\begin{array}{c}\text { A empresa tem } \\
\text { consciência da } \\
\text { importância e dos } \\
\text { impactos da SER, } \\
\text { incluindo consciência } \\
\text { dos impactos } \\
\text { estratégicos; missão, } \\
\text { visão e valores; e, } \\
\text { estratégias relacionadas } \\
\text { aos stakeholders no } \\
\text { contexto RSE? }\end{array}$ & 3 \\
\hline & $\begin{array}{l}\text { Ações de } \\
\text { RSE com } \\
\text { foco no } \\
\text { público } \\
\text { interno } \\
\text { (GOMES, } \\
\text { 2006) }\end{array}$ & $\begin{array}{l}\text { A empresa possui código } \\
\text { de ética formal; gestão } \\
\text { de carreiras; inclusão } \\
\text { social e apoio à } \\
\text { diversidade; práticas de } \\
\text { prevenção à acidentes de } \\
\text { trabalho; práticas } \\
\text { voltadas à satisfação dos } \\
\text { funcionários e promoção } \\
\text { à qualidade de vida do } \\
\text { trabalho? }\end{array}$ & 13 \\
\hline & $\begin{array}{l}\text { Ações de } \\
\text { RSE com } \\
\text { foco nos } \\
\text { fornecedores } \\
\text { (GOMES et } \\
\text { al. }(2005)\end{array}$ & $\begin{array}{c}\text { A gestão dos } \\
\text { fornecedores da empresa } \\
\text { está alinhada aos } \\
\text { aspectos da SER? }\end{array}$ & 7 \\
\hline
\end{tabular}




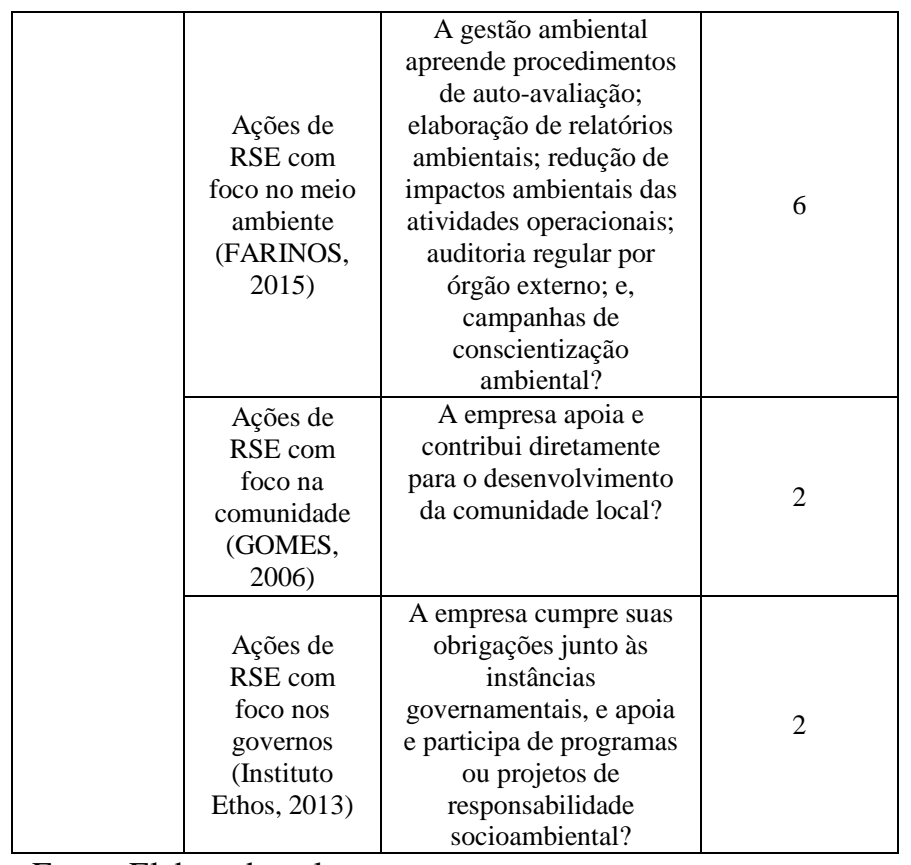

Fonte: Elaborado pelos autores.

Cada questão está apoiada às referências teóricas de sua categoria correspondente, associando os objetivos da pesquisa com os apontamentos da revisão de literatura. A categorias de análise são complementares e interdependentes, facilitando o entendimento de todo o processo que envolve a RSE. No Anexo I estão todas as questões aplicadas no estudo.

\subsection{Caracterização das Empresas Familiares}

Neste trabalho buscou-se uma amostra de empresas heterogêneas, no que tange ao mercado de atuação, porte, ciclo de vida e localização geográfica. A Tabela 2 apresenta uma breve descrição de cada uma das empresas analisadas, ambas localizadas no interior do Estado de São Paulo:

Tabela 2. Descrição das empresas inquiridas para o estudo.

\begin{tabular}{|c|c|c|c|c|c|c|}
\hline 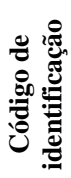 & 离 & 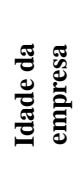 & 产 & 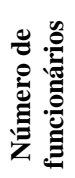 & 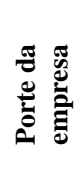 & 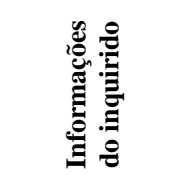 \\
\hline E1 & $\begin{array}{c}\text { empresa } \\
\text { atuante na } \\
\text { produção e } \\
\text { venda de } \\
\text { fertilizantes } \\
\text { para o ramo } \\
\text { agrícola }\end{array}$ & $\begin{array}{c}48 \\
\text { anos }\end{array}$ & $\begin{array}{l}\frac{0}{0} \\
\frac{0}{2} \\
\frac{8}{\pi} \\
\frac{\pi}{0} \\
\frac{0}{\alpha}\end{array}$ & 25 & $P$ & $\begin{array}{c}\text { Gerente } \\
\text { Logístico e é } \\
\text { funcionário da } \\
\text { empresa há } 23 \\
\text { anos }\end{array}$ \\
\hline
\end{tabular}

\begin{tabular}{|c|c|c|c|c|c|c|}
\hline E2 & $\begin{array}{l}\text { empresa } \\
\text { atuante no } \\
\text { comércio } \\
\text { de insumos } \\
\text { agrícolas }\end{array}$ & $\begin{array}{c}30 \\
\text { anos }\end{array}$ & 蛋 & 50 & $\mathrm{P}$ & $\begin{array}{c}\text { Auxiliar } \\
\text { Administrativo } \\
\text { e é funcionário } \\
\text { da empresa há } \\
16 \text { anos }\end{array}$ \\
\hline E3 & $\begin{array}{c}\text { empresa } \\
\text { industrial } \\
\text { atuante no } \\
\text { setor } \\
\text { metalúrgico } \\
\text { e fabricante } \\
\text { de } \\
\text { implemento } \\
\text { s agrícolas } \\
\end{array}$ & $\begin{array}{c}88 \\
\text { anos }\end{array}$ & 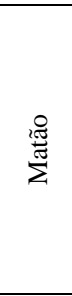 & 1400 & G & $\begin{array}{l}\text { Gerente de } \\
\text { Recursos } \\
\text { Humanos e é } \\
\text { funcionário da } \\
\text { empresa há } \\
\text { quatro anos }\end{array}$ \\
\hline E4 & $\begin{array}{c}\text { empresa } \\
\text { industrial } \\
\text { atuante no } \\
\text { setor de } \\
\text { implemento } \\
\text { s agrícolas }\end{array}$ & $\begin{array}{c}80 \\
\text { anos }\end{array}$ & 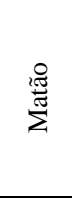 & 2100 & G & $\begin{array}{l}\text { Vendedor e é } \\
\text { funcionário da } \\
\text { empresa há } 20 \\
\text { anos }\end{array}$ \\
\hline E5 & $\begin{array}{l}\text { empresa } \\
\text { industrial } \\
\text { atuante no } \\
\text { setor de } \\
\text { máquinas } \\
\text { agrícolas }\end{array}$ & $\begin{array}{c}60 \\
\text { anos }\end{array}$ & 丞 & 136 & M & $\begin{array}{c}\text { Técnico de } \\
\text { Segurança do } \\
\text { Trabalho e } \\
\text { Gestor de } \\
\text { Recursos } \\
\text { Humanos, e é } \\
\text { funcionário da } \\
\text { empresa há três } \\
\text { anos } \\
\end{array}$ \\
\hline E6 & $\begin{array}{c}\text { empresa } \\
\text { atuante no } \\
\text { setor de } \\
\text { nutrição } \\
\text { vegetal }\end{array}$ & $\begin{array}{c}19 \\
\text { anos }\end{array}$ & $\begin{array}{l}\stackrel{0}{2} \\
0 \\
\stackrel{0}{0} \\
\sum\end{array}$ & 48 & $\mathrm{P}$ & $\begin{array}{c}\text { Diretor } \\
\text { Comercial é } \\
\text { funcionário da } \\
\text { empresa desde } \\
\text { sua fundação }\end{array}$ \\
\hline E7 & $\begin{array}{c}\text { empresa } \\
\text { atuante no } \\
\text { setor de } \\
\text { nutrição } \\
\text { vegetal }\end{array}$ & $\begin{array}{c}19 \\
\text { anos }\end{array}$ & 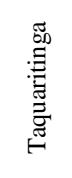 & 20 & $\mathrm{Mi}$ & $\begin{array}{l}\text { Engenheiro } \\
\text { Agrônomo e é } \\
\text { funcionário da } \\
\text { empresa há oito } \\
\text { anos }\end{array}$ \\
\hline E8 & $\begin{array}{l}\text { empresa } \\
\text { atuante no } \\
\text { setor de } \\
\text { fruticultura }\end{array}$ & $\begin{array}{c}30 \\
\text { anos }\end{array}$ & 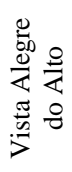 & 130 & $\mathrm{M}$ & $\begin{array}{c}\text { Gerente } \\
\text { Agrícola e é } \\
\text { funcionário da } \\
\text { empresa há } \\
\text { cinco anos }\end{array}$ \\
\hline
\end{tabular}

P: pequeno porte; M: médio porte; Mi: Microempresa; G: grande porte.

Fonte: Elaborado pelos autores.

\section{Resultados e discussão}

4.1 Desenvolvimento da empresa em relação à Responsabilidade Social Empresarial (SER)

As questões foram discutidas de forma aberta com os entrevistados e posteriormente o questionário foi preenchido pelo próprio entrevistador com base em suas percepções. A média das notas atribuídas para cada questão do tópico, resultando na nota final da empresa analisada no que tange ao desenvolvimento em relação à responsabilidade social variaram entre 3 e 4,8. Isso demonstra que a grande maioria das empresas analisadas se mostrou a favor da ideia de 
que a responsabilidade é, de fato, tema altamente relevante no contexto organizacional. Destaque para a E3, cujo discurso do entrevistado revela que a empresa tem projetos audaciosos com relação ao seu futuro no que tange à responsabilidade social: "Nós temos uma política socioambiental que está sendo trabalhada e divulgada pela hierarquia da empresa. Agora estamos iniciando a divulgação para o pessoal mais simples né? Para decodificar isso de uma maneira que eles entendam melhor. [...] também temos um projeto na empresa que nos remete a 2028, que será o ano do nosso centenário, projetando que a empresa esteja entre as 50 melhores empresas para se trabalhar no país" (E3). Este projeto da empresa pauta-se na elaboração da política sócio ambiental da empresa e tem sido elaborado e implementado por um comitê formado pelos próprios funcionários, conforme relatado a seguir:

"[...] temos que escrever a política socioambiental da empresa e dentro disso montamos um grupo com um cara da exportação, uma pessoa do jurídico, um cara do chão de fábrica, peguei um cara do ambulatório médico, peguei um cara do RH, então nós juntamos um pouco de cada área [...] para termos uma visão holística." (E3)

O envolvimento dos funcionários para a implementação de uma política socioambiental é uma atitude que vai de encontro às ideias de Passador (2002), que afirma que agir de forma socialmente responsável não se trata apenas de doar dinheiro, mas sim de mobilizar a empresa em prol de uma causa. Além disso, o pensamento em longo prazo da E3 também é um aspecto positivo a ser ressaltado, pois, segundo Araújo (2006), a responsabilidade social deve apresentar uma dimensão de longo prazo, em que as empresas passam a tomar consciência da necessidade de agregar este conceito à sua cultura organizacional.

No entanto, mesmo que a gestão da empresa esteja consciente da importância do tema, ficou claro que a responsabilidade social ainda é um conceito embrionário para a gestão da empresa e ainda não há uma associação direta entre a responsabilidade social e a estratégia empresarial: cerca de dois meses. [...] ainda não se associou a política socioambiental a negócios efetivamente [...] como é um conceito trabalhado internamente, ainda não foi massificado para a sociedade" [...] Depois que a diretoria concordar com a política socioambiental, vamos divulgar com o restante da organização." (E3)

Analisando pela ótica do modelo de reatividade de Ackerman, a E3 está em fase de transição entre a fase dois e a fase três, ou seja, recém concluiu a elaboração do seu plano socioambiental e está iniciando a fase de implementação e divulgação interna da política, que, de acordo com Stoner e Freeman (1985), é a fase que normalmente mais demora a ocorrer.

Por outro lado, ficou nítido que, para algumas empresas, o conceito da responsabilidade social é pouco considerado por parte de seus gestores, como pode ser observado no trecho do discurso a seguir:

“[...] na agricultura, o próprio
agricultor não está preparado a
enfrentar questões
socioambientais. Se você falar
para um agricultor preservar
uma nascente, preservar uma
mata, preservar a qualidade do
funcionário, isso não é bem
aceito não. [...] o produtor não
vai plantar uma árvore na
propriedade e perder espaço de
terra [...] e no social é muito pior,
ele vai falar 'pro' cara trabalhar
das seis da manhã às seis da
tarde, pagar R\$ 800 e se ele não
quiser, tem uma fila de gente
esperando". (E7)

Para outras empresas ainda, o conceito é conhecido e inclusive incorporado em sua missão, mas a aplicabilidade é muito baixa. Além disso, quando o conceito é aplicado estrategicamente, ele se dá por imposições legais e não por iniciativa voluntária dos sócios ou gestores.

"[...] a responsabilidade social
até está incorporada à missão da
empresa, mas só está no papel,
isso é um fato. [...] isso (a
responsabilidade social) está na
"vitrine", mas não é aplicável
para a empresa. [...] a gente tem 
uma responsabilidade em alguns produtos porque a lei bateu em cima e não porque a empresa quis se moldar a isso. [...] se de fato a empresa se preocupar muito com o social, de certa forma a estratégia passa a não ser tão competitiva, dentro da lógica deles". (E4)

"Eu penso assim: se o social sequer ameaçar um pouquinho da questão capitalista, ele já é deixado de lado. [...] o consumidor não reconhece a importância disso, só se você fizer alguma coisa que venha constar na mídia como uma coisa ruim, aí sim, mas até então você não vende um produto, não faz nada baseado em responsabilidade social. [...] É uma situação conflitante, muitas vezes o sindicato faz a empresa cumprir algumas questões de responsabilidade social, a empresa é obrigada a fazer". (E4)

Ambos os trechos acima retratam o que Araújo (2006) chama de "justiça" e "obrigações sociais" em detrimento da responsabilidade social. De acordo com o autor as ações da organização salvo as que permeiam o campo da legalidade, podem ser caracterizadas como solidárias, do contrário tratam-se de obrigações sociais.

Outro ponto relevante que tangencia este tópico são as afirmações que tiveram mais discordâncias e mais concordâncias por parte dos gestores. As afirmações mais rejeitadas foram: "[a responsabilidade social] gera novos produtos" e "[a responsabilidade social] está incorporada nas estratégias". Por outro lado, as afirmações com maior índice de concordância por parte dos gestores foram: "[a responsabilidade social] melhora a reputação da empresa", "[a responsabilidade social] preocupa-se com o bemestar do ser humano" e "[a responsabilidade social] preserva o ambiente externo da empresa". Esta informação evidencia o fato de que as empresas familiares têm consciência da importância do conceito da responsabilidade social e dos benefícios que traz à empresa e aos seus stakeholders, porém ainda não o veem como um aspecto de diferenciação ou de criação de valor.

\subsection{Alinhamento estratégico às práticas de RSE}

Algumas das questões discutidas neste tópico foram: "a empresa tem consciência da importância e dos impactos estratégicos da responsabilidade social empresarial?" e "a missão, visão e valores da empresa incluem questões relacionadas à responsabilidade social empresarial?". A média das notas atribuídas para cada questão do tópico, resultando na nota final da empresa analisada no que tange ao alinhamento estratégico de cada uma em relação à responsabilidade social, variaram entre 1 e 5 .

A E3 e E6 obtiveram o valor mais alto. O discurso de ambas as empresas, relatado abaixo, reforça bem o resultado obtido:
“A política socioambiental vem alicerçar ainda mais isso, qualquer decisão da empresa passa por um workflow de aprovação, passando por RH e pela área de segurança e meio ambiente. Nem sempre o cara da engenharia tem a visão técnica que nós temos de um impacto que pode ser causado. Aí eu vejo, por exemplo: a substituição de uma máquina pode gerar desconforto para o usuário, pode gerar poluição, aí neste caso a área de segurança do trabalho e meio ambiente não concorda. Então isso é passado em um A3 e só é aceito se for aprovado por todos." (E3)
" $\mathrm{Na}$ tomada de decisão da empresa sempre são levados em conta os impactos ambientais. Por exemplo, quando vamos fabricar um produto que sua matéria prima seja volátil, fazemos um procedimento de "lavar o ar" antes de emitir a atmosfera, uma espécie de purificação. [...] Aqui na empresa, a responsabilidade social é praticada de forma voluntária, a alta gestão busca sempre proporcionar o bem- estar tanto do público interno como externo." (E6)

Cabe ressaltar que a avaliação técnica para aprovação de decisões que possam causar impacto ambiental vai de encontro com as ideias de Gomes (2004), que afirma que é de extrema importância considerar os impactos ambientais na tomada de decisão organizacional. Além disso, a atitude 
mencionada pelo representante da E6 em praticar a responsabilidade de forma voluntária corrobora com o discurso de Araújo (2006), que destaca que nem sempre a responsabilidade social está sendo praticada de maneira voluntária e solidária pelas empresas. No caso de ações exigidas por lei e que visam o direito público, não se trata de solidariedade, e sim justiça.

$\mathrm{Na}$ contramão das empresas mencionadas acima, foi possível observar resultados com baixo grau de concordância em relação às afirmações do tópico, como é o caso da E1 (1), que obteve a menor das médias e da E4 $(1,5)$ e E7 $(2,5)$ que obtiveram uma média pouco acima da primeira, porém abaixo das demais. $\mathrm{O}$ discurso apresentado por cada uma dessas evidencia este resultado:

"Eu acho que, de imediato, não tem muita cobrança e no mercado nosso não tem como aplicar [ações de cunho sócio responsável]. Teria que fazer um estudo de ação para saber como a gente conseguiria fazer uma campanha eficiente nessa área". (E1)

"Como a empresa vê a responsabilidade social? Bom, pelo que eu acredito e vivencio, é pouco importante. [...] inclusive nesse momento da empresa, de reestruturação, a questão social está sendo deixada de lado. As pessoas têm que cumprir metas muitos rígidas, então elas passam por cima do social de qualquer forma. Se o social fizer uma pequena ameaça em lucro ou de perda de competitividade, a empresa não vai se preocupar com isso". (E4)

"Discutimos um pouco o ambiental entre nós, mas isso não impacta muito na tomada de decisão. [...] Nosso produto não impacta tanto no meio ambiente". (E7)

A visão dos gestores de cada uma das três empresas supracitadas é definida por Bateman e Snell (2006) como "antiquada". De acordo com os autores, a busca pela maximização do lucro em detrimento de todo e qualquer aspecto socioambiental, está se tornando cada vez mais inconsistente. Gomes, Santos e Gomes (2005) ainda reforçam que no universo das empresas familiares de micro e pequeno porte, o link entre as ações de cunho sócio responsável e o planejamento estratégico é cada vez menos evidente, uma vez que a busca pela sobrevivência é seu principal foco e a responsabilidade social é deixada em segundo plano.

Dentre as afirmações deste tópico, a que teve um maior índice de concordância por parte dos entrevistados foi: "A empresa tem consciência da importância e dos impactos estratégicos da responsabilidade social empresarial", sendo praticamente uma unanimidade entre todas as empresas. Por outro lado, a afirmação "As estratégias da empresa são determinadas dentro de um contexto sócio responsável" foi a que teve o menor índice de concordância. Este fato revela que, se por um lado, as empresas sabem o quão importante é a responsabilidade social do ponto de vista estratégico, por outro lado, poucas de fato associam o conceito ao planejamento estratégico organizacional. Serpa e Fourneau (2007) reiteram esta questão, afirmando que muitas empresas familiares não sabem como pensar a responsabilidade social estrategicamente, nem tampouco operacionalizar as ações de responsabilidade social junto aos seus stakeholders. Em vista disso, Gonçalves, Desiderio e Gutierrez (2006) sugerem que essas organizações contem com a colaboração de especialistas que saibam conduzir a empresa rumo a projetos de responsabilidade social.

\subsection{Ações de RSE voltadas ao público interno}

Neste momento, buscou-se compreender não só o grau de envolvimento das empresas com seus funcionários, mas também a capacidade dessas em criar um ambiente de trabalho pautado em diversidade, respeito, proporcionando condições adequadas de trabalho e remuneração justa.

Dentre as ações direcionadas a um mesmo stakeholder há algumas prioritárias às empresas e outras praticamente esquecidas. Neste caso, as ações mais visadas pelas empresas foram "benefícios" $(4,4)$ e "prevenção de acidentes" $(4,3)$, enquanto que as ações menos consideradas pelas empresas entrevistadas foram "clima organizacional" $(1,6)$ e "código de ética" $(1,8)$.

Um fato a ser destacado é que as duas

Revista de Negócios, v. 23, n. 4, p. 47-69, October, 2018. 
variáveis mais levadas em conta pelas empresas são assuntos basicamente de seu próprio interesse. No que tange os benefícios, como assistência médica e odontológica, estes fazem parte do planejamento tributário das empresas, também denominado elisão físcal, proporcionando a elas dedução no pagamento de tributos à receita federal, como argumentado por Marins (2002). Já o acidente de trabalho é um assunto de extrema preocupação por parte das empresas por conta das diversas consequências previdenciárias e trabalhistas que traz. A Constituição Federal dispõe em seu artigo $7^{\circ}$, inciso XXVIII, que é direito dos trabalhadores o "seguro contra acidentes do trabalho, a cargo do empregador, sem excluir a indenização a que este está obrigado, quando incorrer em dolo ou culpa". Em paralelo, a Lei $8.213 / 91$ em seu artigo 118, estabelece que "O segurado que sofreu acidente do trabalho tem garantida, pelo prazo mínimo de doze meses, a manutenção do seu contrato de trabalho na empresa, após a cessação do auxílio-doença acidentário, independentemente de percepção de auxílio-acidente". A jurisprudência, portanto, diz respeito a ambos os aspectos acima listados, demonstrando que a atuação das empresas neste sentido tem explicação tanto na elisão fiscal, como na obrigatoriedade legal e não necessariamente no desejo voluntário de agir de forma socialmente responsável.

Conforme supracitado, as variáveis que têm menor aplicabilidade às empresas são "clima organizacional" e "código de ética", que diferentemente das questões acima, não são assuntos impostos pela jurisprudência e, portanto, são liberalidades as quais as empresas familiares do agronegócio, em geral, não têm dado a devida importância. Esta atitude é discutida por alguns dos autores supracitados, como o Instituto Ethos (2013) que reforça que a empresa socialmente responsável deve prezar por uma gestão baseada na relação ética e transparente com seus stakeholders e Gomes (2004), que afirma que as empresas socialmente responsáveis devem tornar o ambiente empresarial o mais agradável possível de se conviver, para que o trabalho se torne produtivo e prazeroso.

Outro aspecto que merece ressalva é a variável "diversidade", que se enquadrou entre uma das menos pontuadas, demonstrando o desinteresse das organizações em desenvolver um ambiente onde pessoas de faixas etárias, gêneros, culturas e interesses distintos convivam em harmonia e gozem dos mesmos direitos e deveres. Além disso, a diversidade permite a inclusão de pessoas com qualquer tipo de deficiência dentro da organização, sem que haja distinção em relação aos seus colegas de trabalho. A definição de Gomes (2006) a respeito de diversidade reforça a relevância do tema no contexto organizacional. $\mathrm{O}$ autor afirma que, para que uma empresa seja considerada socialmente responsável, é fator chave o respeito pelo ser humano, valorizando as diversidades e evitando discriminações ao oferecer oportunidades iguais para pessoas especiais.

O discurso do gestor deixa claro o nível de desenvolvimento das ações de responsabilidade social com foco no público interno da E3 frente às demais entrevistadas. A seguir são evidenciadas algumas ações da empresa neste sentido:

\begin{abstract}
Nós somos hoje uma empresa aberta. Você sugerir, querer discutir, "chutar a porta" e entrar "pra" falar, qualquer um pode fazer, inclusive o pessoal da fábrica entra aqui pra falar. $\mathrm{O}$ RH é bem atuante, tudo passa pelo $\mathrm{RH}$, o funcionário tem acesso direto a mim, ao presidente e a partir daí as decisões são tomadas (E3).
\end{abstract}

Temos um programa que busca
trazer uma vida mais saudável
aos funcionários e seus
familiares. Organizamos uma
caminhada, é a segunda
caminhada este ano, fizemos a
primeira e deram 300 pessoas,
fizemos a segunda e deram
quase 600 pessoas. Fizemos
também o encerramento da
SIPAT com a presença da
família, os filhos, com lanche,
brincadeiras com os
funcionários e todos os
familiares, foram mais de 800
pessoas (E3).

O discurso acima evidencia a preocupação da empresa em proporcionar ao funcionário um ambiente de trabalho harmônico, saudável e democrático. Um ponto de destaque é que as ações supracitadas não foram impostas à empresa, mas sim ações propostas voluntariamente pela alta gestão em prol do clima organizacional. A ação da alta gestão de acatar sugestões e propostas de melhorias em todas as áreas da organização vai de

Revista de Negócios, v. 23, n. 4, p. 47-69, October, 2018. 
encontro com o conceito de "gestão participativa", definido pelo Instituto Ethos como a prática de "[...] possuir mecanismos para ouvir, avaliar e acompanhar posturas, preocupações, sugestões e críticas dos empregados, com o objetivo de agregar novos aprendizados e conhecimentos" (INSTITUTO ETHOS, 2013, p. 24).

Em contraste com o resultado positivo obtido pela E3, é possível averiguar que a E4 obteve a menor das médias neste quesito, caracterizando-a como uma empresa pouco atuante frente às necessidades de seu público interno. Alguns trechos do discurso reforçam essa afirmativa:

Temos um código de ética que não é compartilhado, são regras que nasceram com a empresa. A gente que está na empresa há muito tempo sabe o que tem que fazer, o que não tem que fazer, mas isso não é compartilhado para todos não (E4).

[...] às vezes você tem que passar uma ideia de mudança, sugestão, ao seu superior, mas muitas vezes ele não acata porque pode ser que ela não venha a agradar muito ele, então muitas ideias "morrem" na hierarquia. [...] Isso ocorre porque às vezes seu superior pode se sentir ameaçado pela sua ideia. As pessoas se sentem donas do cargo e não querem mudanças, as mudanças não são vistas como maneiras de melhorar alguma coisa (E4).

Primeiramente, em relação à ausência de um código de ética formalizado, o Instituto Ethos (2013), aconselha que as empresas caracterizadas como socialmente responsáveis criem um código de ética e o compartilhem com seus funcionários, estabelecendo os valores e princípios incorporados aos processos de trabalho, bem como as atitudes e comportamentos esperados por todos os funcionários da empresa.

Já com relação à resistência a novas ideias na empresa, o Instituto Ethos, ainda dentro do conceito de "gestão participativa" prega a importância da criação de programas de incentivos e reconhecimento de sugestões dos empregados para melhoria dos processos. No entanto, conforme discurso do representante da $\mathrm{E} 4$, a hierarquia pouco flexível e o receio dos gestores em terem seus cargos comprometidos, não permitem que este conceito seja aplicado na organização, impactando negativamente no crescimento do negócio e na satisfação dos funcionários.

\subsection{Ações de SER voltadas aos fornecedores}

Estas e outras variáveis foram avaliadas em cada uma das empresas e os resultados obtidos ficou evidente que dentre as ações direcionadas ao stakeholder fornecedor, as mais levadas em conta pelas empresas são: "relação de longo prazo" e "critérios de seleção", enquanto que as menos consideradas são "auditorias socioambientais" e "parceria em projetos de responsabilidade social". Primeiramente, em relação às variáveis dadas como prioritárias pelas empresas, a "relação de longo prazo" entre empresas / fornecedores demonstra que grande parte das empresas analisadas considera importante o estabelecimento de um vínculo duradouro pautado em confiança e colaboração, conforme observado no discurso a seguir:

A cada entrega ou serviço do
fornecedor fazemos o
acompanhamento
desempenho. São feitas as
avaliações de desempenho e
informamoso fornecedor como
a companhia está classificando o
seu atendimento e quais são as
ações necessárias para que haja
alguma melhoria no processo.
[...] Buscamos transparência nos
negócios, sempre buscamos uma
relação próxima e de longo
prazo com os fornecedores. (E6)

A segunda variável que diz respeito ao estabelecimento de critérios claros na definição de fornecedores também obteve alta pontuação e o discurso a seguir reforça esta afirmação: "Nós temos tudo [critérios de seleção de fornecedores] previsto na política socioambiental, as empresas que não se adequam são orientadas por nós neste sentido" (E3).

O estabelecimento destes critérios é amplamente discutido na literatura do tema e abordado por alguns autores como fator determinante, já que há uma relação evidente de sinergia e interdependência entre empresa e fornecedor (MACEDO, 2006, 2007). Em alguns trechos dos Indicadores Ethos de Responsabilidade Social são mencionados e discutidos aspectos

Revista de Negócios, v. 23, n. 4, p. 47-69, October, 2018. 
inerentes a esta relação, como a relevância em "adotar critérios de compra que consideram a garantia de origem, para evitar a aquisição de produtos piratas, falsificados ou frutos de roubo de carga" (INSTITUTO ETHOS, 2013, p. 48). Duas das variáveis deste quesito apresentaram médias baixas em comparação às demais, sendo a menor delas relacionada à realização de auditorias ambientais junto aos fornecedores, seguida da variável: parcerias empresa / fornecedor na realização de projetos de responsabilidade social.

Pode-se observar que, mais uma vez, a E3 lidera o ranking, reforçando sua aderência à responsabilidade social já observada nos tópicos anteriores, seguida da E8 com média pouco abaixo da primeira, porém acima das demais empresas. Por outro lado, desta vez, três empresas obtiveram as menores médias, E1, E4 e E5. Tanto E3, como E8 se destacam neste quesito principalmente em variáveis como "relações de longo prazo", "parceria em projetos de RS" e "critérios de seleção", conforme trechos do discurso de seus representantes:

Os fornecedores participam das nossas ações, doam itens e produtos para auxiliar nestas ações. [...] nós também participamos diretamente das ações dos nossos fornecedores: eventos, festas, eles sempre pedem a nossa presença e nós participamos. [...] $80 \%$ dos nossos fornecedores são parceiros de longa data. (E3)

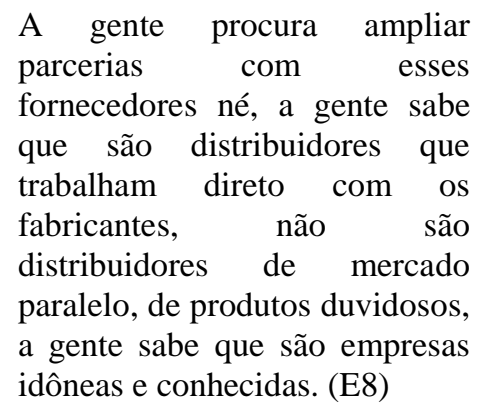

A visão de ambas as empresas vai de encontro com o que a literatura prega como uma relação cooperativa entre empresas e fornecedores em termos sociais, ambientais e até mesmo econômicos. Conforme afirmam Bendixen e Abratt (2007), é cada vez mais frequente o enfoque da responsabilidade social corporativa à cadeia de suprimentos e o discurso de ambas as empresas retrata esta realidade.

$\mathrm{Na}$ contramão destas empresas com bom desempenho no quesito, E1, E4 e E5 obtiveram as menores médias dentre as entrevistadas e o discurso de seus representantes explica este resultado:

Não tem critério definido para
fornecedores, temos no máximo
cinco matérias primas, então
como são poucos fornecedores
no mercado, escolhemos os que
têm. [...] não temos nenhum
fornecedor que participa de
algum projeto ou ação em
conjunto. (E1)

Para seleção de fornecedores o critério que prevalece é custo. [...] Eu desconheço de qualquer projeto social ou ambiental de fornecedor que a empresa participe. [...] Se você tem um fornecedor chave que você não pode ficar sem ele, você "tem que aguentar ele", já se forem outros, se não tiver atendendo e tiver outro que concorre com ele, ele "tá" fora. (E4)

Que eu saiba a empresa nunca participou de nenhum projeto de fornecedor, não tem essa parceria, pelo menos desde que estou aqui. (E5)

Os discursos relatados acima deixam claro que a relação entre essas empresas e seus fornecedores é meramente comercial sem nenhum vínculo colaborativo. Conforme já citado anteriormente neste trabalho, Harrison e St. John (1996) explicam que em épocas passadas era comum a ideia de que os stakeholders externos não poderiam ser gerenciados, visto que não faziam parte da hierarquia organizacional, no entanto, esta visão já se tornou retrógrada. Considerando o apontamento destes autores, o comportamento destas empresas é tido como ultrapassado e deve ser revisto caso pretendam adotar uma gestão socialmente responsável em parceria com a sua cadeia de suprimentos.

\subsection{Ações de RSE voltadas ao meio ambiente}

Neste tópico, a análise será direcionada às ações das empresas familiares do agronegócio que buscam minimizar o impacto ao meio ambiente.

Revista de Negócios, v. 23, n. 4, p. 47-69, October, 2018. 
Autores como Gomes, Santos e Gomes (2005); Alves, Raphaelli e Fangueiro (2006) afirmam ser de extrema importância para as empresas de qualquer porte ou setor preservar nossos recursos ambientais, bem como mitigar quaisquer impactos que o processo produtivo possa causar no meio ambiente, a fim de não comprometer a capacidade das gerações futuras satisfazerem suas próprias necessidades.

As notas obtidas pelas empresas, em média, trabalham de forma homogênea com apenas um destaque para a variável "certificação ambiental", que apresentou a menor média dentre as demais. Os destaques positivos são das variáveis "autoavaliação ambiental" e "minimização de impactos ambientais" que, contudo, praticamente se equiparam às demais.

O prestígio de uma certificação ambiental é apontado no relatório de indicadores de responsabilidade social do Instituto Ethos e, de acordo com o mesmo, a importância não se dá somente em possuir a certificação, mas também priorizar fornecedores que a possuem, e neste caso, a E3 merece destaque: "Em compras nós temos vários fornecedores, mas os mais significativos são empresas de grande porte certificadas em termos sócio ambientais." (E3).

No entanto, cabe ressaltar que nenhuma das empresas analisadas possui quaisquer certificações ambientais, e inclusive, muitas delas nem sequer as conhecem. Uma possível explicação para esta questão é dada por Gomes, Santos e Gomes (2005) que afirmam que grande parte das empresas familiares consideram questões de cunho ambiental e até mesmo social um luxo ao qual elas não podem se dar, já que o objetivo primeiro é a sobrevivência e busca por um espaço no mercado.

Já com relação às variáveis que obtiveram as melhores pontuações, é necessário ressaltar positivamente as práticas de "autoavaliação ambiental" e "minimização dos impactos ambientais" por parte das empresas, mesmo sem possuírem qualquer tipo de certificação ambiental. Gomes (2004) dá destaque à relevância da avaliação ambiental e posterior minimização dos impactos, afirmando que impactos ambientais são inevitáveis, todavia cabe à empresa administrá-los, evitando os negativos e expandindo os positivos.

O Instituto Ethos (2013) ainda complementa, reforçando a importância não somente de avaliar estes impactos, mas também de estabelecer metas de redução do consumo de água, de redução de geração de resíduos sólidos, de redução de emissão de $\mathrm{CO} 2$, etc., acompanhandoas e atualizando-as periodicamente.

Os resultados revelaram uma grande superioridade de algumas empresas em relação a outras neste quesito. A E6 e a E8 obtiveram as maiores notas, alcançando a média 4,5 , enquanto que a E1 obteve média 1,5, bem abaixo das demais.

O discurso de ambos os representantes, tanto de E6 como de E8 deixam claro esta preocupação das empresas com a preservação dos recursos ambientais e com a mitigação dos impactos causados ao meio ambiente:

Sim, a gente faz o possível para
minimizar qualquer impacto
ambiental. Por exemplo, tanto a
água como o ar passa por um
tratamento para voltar a
atmosfera depois de passar pelos
nossos processos. [...] [No
momento de escolher as nossas
matérias primas], nós sempre
damos preferência as que geram
menor impacto e as que têm
menor volatilidade (E6).

Com relação embalagens vazias, a gente faz o descarte correto [...] a empresa produz alguns outros resíduos e ela trata tudo isso, ela tem estação de tratamento de agua e tudo mais. [...] os resíduos do tipo industriais, que são resíduos do processamento, a gente utiliza como composto orgânico, como fertilizante orgânico para a fruticultura. [...] os treinamentos que fazemos de segurança também abordam questões do meio ambiente, a gente aprende que é importante recolher as embalagens, que precisa acondiciona-las de forma correta e tudo mais, pra gente no campo, tem muitos treinamentos nesta área, sobre contaminação de curso d'água, sobre transporte dos produtos, enfim (E8).

Em ambos os discursos, fica evidente que a preservação ambiental está incorporada à estratégia destas empresas, seja controlando a emissão de resíduos, seja selecionando matérias primas de menor impacto, seja proporcionando treinamento de conscientização ambiental a seus funcionários. Esta atitude vai de encontro com a

Revista de Negócios, v. 23, n. 4, p. 47-69, October, 2018. 
premissa proposta por Arrow et al. (2012) que afirmam que as organizações devem se concentrar em utilizar cada vez menos recursos e gerar cada vez menos degradação ao meio ambiente, preocupando-se com as consequências em longo prazo dos impactos ambientais às gerações futuras.

Apesar de não ter alcançado média tão alta quanto às duas empresas supracitadas, a E3 também merece destaque no quesito, já que vem desenvolvendo há tempos uma política socioambiental que está prestes a ser implementada e compartilhada com todos os seus funcionários, conscientizando-os acerca do tema, conforme discurso de seu representante:

Estamos nos preparando para implementar a ISO 14000, mas todo o trabalho de controle de resíduos é feito por nós desde a geração. A gente vem trabalhando preventivamente $\mathrm{e}$ isso é um trabalho árduo. [...] Como estamos terminando de fazer a nossa política socioambiental, o próximo passo da política é desenvolver a educação ambiental então isso já está quase em fase de execução (E3).

O estabelecimento de uma política socioambiental também é tema apresentado pelo Instituto Ethos (2013) nas diretrizes de responsabilidade social, reforçando que é de extrema relevância que as empresas elaborem a política e a divulguem a todos os funcionários, inclusive registrando-a no condigo de conduta ou na declaração dos valores organizacionais.

Em contrapartida, a E1 obteve a menor média dentre as empresas pesquisadas e no discurso de seu representante fica claro a pouca relevância dada pela empresa às questões de cunho ambiental:

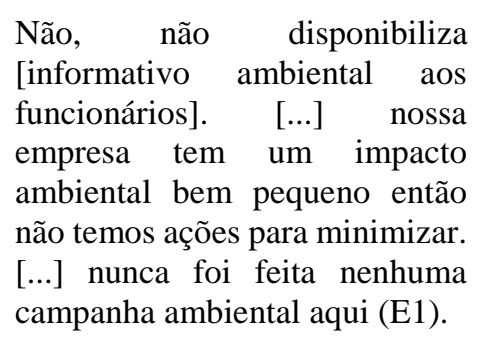

Conforme descrito anteriormente, a E1 é uma empresa atuante na produção e venda de fertilizantes para o ramo agrícola, portanto o seu setor produtivo gera alguns resíduos e utiliza de algumas matérias, conforme mencionado pelo seu próprio representante. No entanto, como a empresa considera pequena a quantidade de resíduos gerados, não há o desenvolvimento de nenhum mecanismo de controle destes, gerando um impacto negativo (mesmo que em pequena dimensão) ao meio ambiente. Além disso, o fato de a empresa não investir em treinamentos de capacitação ambiental com seus funcionários, impede que desenvolvam o senso crítico acerca da importância tema, disseminando internamente a cultura de que não há necessidade em mitigar os impactos ambientais por ela gerados.

\subsection{Ações de RSE voltadas à comunidade}

Melo Neto e Froes (1999, p.79) afirmam que "a filantropia é figurada como o estágio inicial da responsabilidade social, sendo praticada pelos empresários através de doações a entidades assistenciais e filantrópicas, sem maior comprometimento". Os resultados apresentaram a disparidade entre a atuação das empresas familiares em programas de desenvolvimento da comunidade (média 1,6) e a realização de doações ou campanhas assistencialistas (média 3,6). A definição de Gomes, Santos e Gomes (2005), pode explicar a razão pela qual as empresas preferem investir na filantropia em detrimento de programas de desenvolvimento da comunidade. Os autores afirmam que o assistencialismo é o meio mais simples e menos dispendioso de impactar a sociedade positivamente. Cabe ainda ressaltar ações assistencialistas detêm de um caráter paliativo, abrangendo o fomento da caridade, enquanto as ações em prol do desenvolvimento abrangem o fomento da cidadania (SOUSA, 2006). Neste quesito, mais uma vez a E3 obteve uma das maiores médias, juntamente à E1 e E4, enquanto que a $\mathrm{E} 2$ obteve a menor média dentre as analisadas (média mínima). O discurso destas empresas reflete este resultado contrastante:

O pessoal aqui sempre participa
de campanhas. Eles fazem
campanhas de entrega de
agasalhos, o leilão da APAE,
sempre qualquer campanha
deste tipo o pessoal está sempre
colaborando em parceria com as
instituições. Geralmente, eles

Revista de Negócios, v. 23, n. 4, p. 47-69, October, 2018. 
pedem para não anunciar, eles acham que tem que ajudar sem divulgar para ninguém. Desde muito tempo, os donos têm essa visão de ajudar sem vincular como qualquer tipo de propaganda, eles fazem porque querem fazer, eles se sentem melhor assim. (E1)

Temos uma campanha de natal solidário, e temos vários programas diretos com a comunidade. Todo dia eu recebo pedidos de auxílios, doações e patrocínios. Todos os programas que sabemos que são sérios, nós ajudamos sim. (E3)

A empresa tem um convênio desde que nasceu com o hospital local, acredito que ela repasse algum recurso a eles. Além disso, às vezes são feitas campanhas de agasalho também. (E4)

Não, não temos nenhuma campanha aqui na cidade. O que fazemos é divulgar o nome da empresa através das escolas da cidade. A gente tem uma parceria com um barracão de embalagem vazias e todo ano levamos alguns alunos de escolas da cidade para conhecer o barracão e conhecer como é feita a embalagem. (E2)

Por meio dos discursos fica claro que os programas por desenvolvidos por essas empresas pautam-se em uma base assistencialista e nenhum deles enfoca no desenvolvimento da comunidade em longo prazo. Este tipo de ação compactua com o que Carroll (1979) denomina de "responsabilidades discricionárias" que representam as ações de cunho social, voluntário e filantrópico organizadas pelas organizações em prol da comunidade.

Cabe reforçar que a atuação da E1 se dá não sé por meio de ações esporádicas, mas através de parcerias com instituições da cidade, atuando frequentemente em ações de cunho social junto a estas, assim como a E4, que possui um convênio com o hospital da cidade promovendo ações em seu benefício. Ambas as empresas se enquadram na definição de Passador (2002), que afirma que a responsabilidade social não se trata apenas de doar dinheiro, mas sim de fazer parcerias bem articuladas com organizações da sociedade civil para estimular movimentos sociais organizados.

A E2, por outro lado, demonstra em seu discurso que não atua em prol da comunidade, nem sequer em ações de cunho assistencialista. A única ação descrita por seu representante é, na realidade, organizada por uma empresa parceira e o papel da E2 é basicamente apoiar a realização do projeto, divulgando o nome da empresa ao público alvo da ação. A atitude da empresa compactua com a visão de Milton Friedman (1984) de que a responsabilidade social de uma empresa não está relacionada com qualquer tipo de caridade ou assistencialismo junto à comunidade em que está inserida, pelo contrário, o autor afirma que as organizações que concentrarem suas ações em questões sociais tendem a perder competitividade no mercado.

\subsection{Ações de SER voltadas ao governo}

Neste tópico, o objetivo foi entender a visão das empresas familiares acerca da importância da relação esfera pública x esfera privada. Além disso, o tópico tem o intuito de compreender o quão respeitosas são as empresas à normatização legal, trabalhista e tributária do país, bem como quão atuantes são estas empresas no que se refere às ações governamentais em prol da sociedade.

Os resultados apresentaram disparidade entre as ações realizadas pelas empresas familiares por obrigatoriedade legal e as ações realizadas voluntariamente em parceria com a esfera pública. No que tange o cumprimento de obrigações governamentais, Carroll (1979) define-as como "responsabilidades legais" e, neste caso, não há nenhuma liberalidade que isente a empresa de sua obrigação. Araújo (2006) ainda complementa que, ações exigidas por lei e que visam o direito público, não representam solidariedade, e sim justiça e, portanto, o cumprimento da lei não configura a empresa como socialmente responsável. Por outro lado, Milton Friedman (1984), em seu discurso a respeito de responsabilidade social, afirma que as únicas responsabilidades as quais a empresa deve se concentrar é na geração de lucro e no cumprimento de suas obrigações legais, tais como pagamento de salários e tributos.

$\mathrm{O}$ discurso dos gestores demonstra que a relevância deste assunto é uma unanimidade. 
Temos um advogado que trabalha pra gente, sempre cuidando da parte trabalhista, das leis. A gente sempre trabalha da melhor forma possível para que, depois, quando o funcionário sair, ele saia de forma amigável (E7).

A gente tem um departamento fiscal que cuida de toda parte de tributos e quando acontece alguma ação trabalhista a gente tem um advogado terceirizado, mas raramente precisa, pois não temos nenhuma ação, por isso nem temos departamento jurídico aqui dentro (E5).

A empresa tem um departamento jurídico, estamos com quatro advogados diretos e um estagiário. Além disso, temos escritórios jurídicos que nos prestam acessória com assuntos tributários. No dia a dia, nossa equipe interna supre muito bem as demandas que temos. (E3).

Sendo por meio de funcionários, sendo por meio de profissionais terceirizados, todas as empresas possuem uma equipe responsável por garantir que todas as obrigações legais sejam cumpridas em sua totalidade, obedecendo ao que Carroll (1979) define como "responsabilidades legais". Por outro lado, apenas duas delas apresentam ações ou projetos em parceria com a esfera pública, conforme descrito por seus representantes nos trechos a seguir:

Nós cumprimos $100 \%$ da cota de aprendizes. Nós temos 58 aprendizes aqui na fábrica. A gente sempre abre para a comunidade e para funcionários a indicação de filhos. [...] estamos tentando também formar uma parceria com o projeto "Meu Novo Mundo" que é o projeto de PCDs, né. Mas ainda estamos resolvendo alguns entraves políticos entre Ministério do Trabalho e SESI / SENAI, [...] esperamos que dê certo (E3).

A empresa participa fortemente do programa "Mais Alimentos" que é um programa de fortalecimento da agricultura familiar que, de certa forma, fortaleceu a agricultura do campo, mas também fortaleceu a empresa porque ela aproveitou este nicho que o governo abriu com linhas de crédito subsidiadas que começaram a fomentar os pequenos produtores com máquinas e equipamentos agrícolas, vendendo [a um valor] um pouco abaixo do que é praticado no mercado (E4).

Em ambos os casos as empresas demonstraram que estão atentas aos projetos governamentais, buscando participar ativamente de alguns deles.

No caso da E3, o foco é no desenvolvimento profissional de jovens, por meio do programa "Jovem Aprendiz", que é uma iniciativa do Governo Federal com o objetivo de inserir jovens de 14 a 24 anos no mercado de trabalho, desde que estejam matriculados e frequentando alguma instituição de ensino (PRONATEC, 2015). Além deste programa, a empresa ainda pretende investir no projeto "Meu Novo Mundo", uma iniciativa do Depar, da Fiesp, em parceria com a SRTE-SP, que busca preparar pessoas com alguma deficiência para o mercado de trabalho (SESI, 2014).

Já a E4 atua em parceria com a esfera pública no programa "Mais Alimentos", desenvolvido pelo Ministério da Agricultura através do Programa de Fortalecimento da Agricultura Familiar. O programa tem o objetivo de destinar recursos para investimentos em infraestrutura produtiva da propriedade familiar proporcionando melhores condições para a produtividade agrícola do país (MINISTÉRIO DA AGRICULTURA, 2016).

Os resultados apontaram duas empresas em posição de destaque (E3 e E4), enquanto as demais podem ser caracterizadas como regulares, com médias variando entre 3 e 4, com destaque para a E1 que obteve a média 2,5, a mais baixa dentre as empresas analisadas. Dentre as empresas com maiores médias, ambas atuam não somente em prol da normatização legal, por meio do pagamento de tributos e cumprimento da legislação vigente, mas também através do envolvimento em programas governamentais, conforme já citado neste tópico.

Revista de Negócios, v. 23, n. 4, p. 47-69, October, 2018. 
O interesse das empresas em investir em parcerias com o governo é mencionado pelo Instituto Ethos (2013, p. 67) em seus indicadores de responsabilidade social, que estabelece que as empresas socialmente responsáveis deveriam ter "membros de sua alta direção envolvidos na articulação, viabilização e fortalecimento de propostas de caráter socioambiental em diálogo com [...] autoridades públicas, visando sua adoção".

Cabe ainda apontar a empresa com menor nota neste quesito: E1, por conta de seu baixo envolvimento com o âmbito público, evidenciado no discurso de seu representante.

\begin{abstract}
O pessoal da contabilidade e RH que cuida dessa área [legal e tributária]. [...] temos alguns problemas às vezes sim, mas a gente tenta seguir na medida do possível. Não tem empresa perfeita né, são muitos impostos, contas que você não sabe como funciona. [...] não, a empresa não participa de nenhum [programa do governo]. (E1)
\end{abstract}

$\mathrm{O}$ discurso deixa claro que, além de a E1 não se envolver em nenhum programa governamental, a empresa ainda mostra a incapacidade em lidar com questões legais e tributárias. Primeiramente, os departamentos que cuidam destas questões não são os adequados, visto que assuntos da esfera jurídica deveriam estar sob a responsabilidade de um departamento jurídico, ou até mesmo de profissionais terceirizados especialistas no assunto. Além disso, a lei não permite que nenhuma pessoa física ou jurídica cumpra a lei "na medida do possível", ou até mesmo justifique seu descumprimento na grande quantidade de impostos existentes.

O Art. 16. do Código Tributário Nacional de 1996 aponta que, "Imposto é o tributo cuja obrigação tem por fato gerador uma situação independentemente de qualquer atividade estatal específica, relativa ao contribuinte" e, complementando esta definição, neste mesmo código, o Art. 121 diz respeito ao sujeito passivo que "[...] é a pessoa obrigada ao pagamento de tributo ou penalidade pecuniária." Com base no Código Tributário Nacional, concluise que o sujeito passivo (neste caso, a empresa) tem por obrigação cumprir com seu dever tributário junto à esfera pública, estando sujeito a uma penalidade pecuniária. Portanto, fica evidente que a E1 ainda tem alguns aspectos a aprimorar em relação ao seu envolvimento com o governo, não somente em projetos socioambientais, mas também no cumprimento estrito de suas obrigações legais e tributárias.

\subsection{Avaliação geral das empresas}

Com base nas avaliações das ações de responsabilidade social das empresas familiares do agronegócio apresentadas até esta etapa do trabalho, a Figura 1, a seguir, apresenta um panorama geral da responsabilidade social, observando quais dos stakeholders são mais e menos considerados por parte das empresas analisadas. O termo que caracteriza este tópico é "saliência de stakeholder", que, conforme já caracterizado anteriormente neste trabalho, surge da necessidade dos gestores em identificar os diferentes grupos envolvidos com a organização, classificando-os em uma escala de prioridades (DONALDSON; PRESTON, 1995).

Assim como tem sido feito até então, a escala da avaliação vai de 1 a 5 , sendo 1 o stakeholder cujo vínculo é mínimo e 5 o stakeholder cujo vínculo é máximo com as empresas familiares no que se refere às ações de cunho sócio responsável.

Figura 1. Radar: nível de envolvimento das empresas familiares com cada stakeholder.

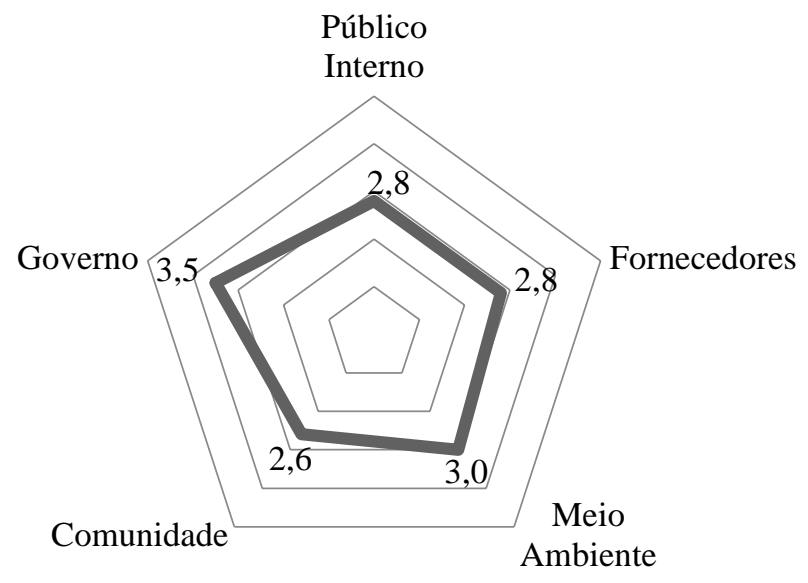

Fonte: elaborado pelos autores.

O radar demonstra que o stakeholder "governo" é o mais considerado pelas empresas familiares do agronegócio em suas ações de cunho sócio responsável, enquanto que o envolvimento com a "comunidade" é o menor dentre todos. Este

Revista de Negócios, v. 23, n. 4, p. 47-69, October, 2018. 
resultado determina a seguinte escala hierárquica de "saliência de stakeholders" para as empresas familiares do agronegócio.

Figura 2. Escala hierárquica "saliência de stakeholders"

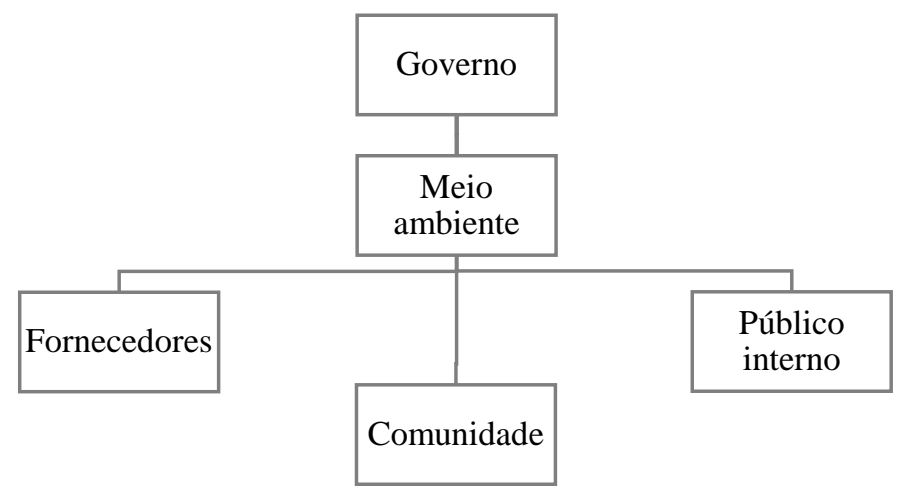

Fonte: elaborado pelos autores.

O maior grau de saliência das empresas ao stakeholder "governo" pode ser explicado pela obrigatoriedade legal que envolve esta relação. Um fato que comprova esta afirmação é a avaliação das empresas 4,8/5 na variável "cumprimento de obrigações governamentais", mesmo com a baixa avaliação na variável "participação em programas governamentais" (2,3/5), demonstrando que é praticamente uma unanimidade entre as empresas a importância do comprometimento com questões legais e tributárias. Esta avaliação geral das empresas demonstra o comportamento "acomodativo" destas, pela ótica do modelo de reatividade social, ou seja, a empresa somente busca se alinhar às exigências do governo e da opinião pública.

Logo em seguida na escala hierárquica, o grau de saliência ao stakeholder "meio ambiente" denota a preocupação das empresas familiares ao impacto de suas operações ao meio ambiente. Mesmo que nenhuma das empresas analisadas goze de certificação ambiental, as médias obtidas nas demais variáveis do quesito refletem o grau de maturidade das empresas em relação aos aspectos ambientais da responsabilidade socioambiental.

O grau de saliência das empresas em relação aos stakeholders "fornecedores" e "público interno" sinaliza que há pontos de melhorias que devem ser explorados em ambos os casos. Em relação aos fornecedores, as principais variáveis que devem ser aprimoradas pelas empresas familiares são: parcerias na realização de projetos de responsabilidade social, bem como a realização de auditorias socioambientais em fornecedores. No que se refere ao stakeholder "público interno", as empresas deixaram a desejar nos quesitos "clima organizacional" e na ausência da elaboração um código de ética formal.

Por último, o stakeholder no menor grau hierárquico de saliência com as empresas familiares foi a "comunidade". A principal razão que justifica este resultado é o baixo envolvimento das empresas com programas de desenvolvimento da comunidade, restringindo suas ações a programas assistencialistas, como, por exemplo, campanhas de doações de alimentos, agasalhos, etc. Isso ocorre principalmente pelo baixo investimento de tempo e recursos financeiros que estas ações exigem.

O nível de envolvimento das empresas familiares com cada stakeholder representa a decisão, mesmo que inconsciente, dos gestores em priorizar alguns em detrimento de outros. $\mathrm{O}$ fato de o "governo" ser o stakeholder com maior nível de saliência (principalmente por conta do cumprimento de obrigações legais) e a "comunidade" o menor (pela falta de ações de desenvolvimento da mesma) deixa claro que as obrigações legais ainda sobressaem amplamente em relação às ações voluntárias. Este resultado compactua com a visão de Milton Friedman (1984), que afirma que a busca por lucratividade aliada ao cumprimento de obrigações legais já são suficientes para caracterização uma empresa como cumpridora de suas obrigações sociais e reitera que quaisquer outras ações de caráter sócio responsável podem prejudicar a competitividade das empresas.

Confrontando os resultados obtidos de "saliência de stakeholders" à teoria da reatividade, pode-se observar que a ação das empresas familiares do agronegócio, em nível macro, está intimamente relacionada com a ideia de que a esfera pública determina o comportamento social das empresas em suas relações secundárias. Por outro lado, no nível micro, fica claro o comportamento "acomodativo" das empresas, ao passo que suas ações pautam-se prioritariamente em um alinhamento as exigências do governo.

É evidente que a "responsabilidade legal", outrora mencionada por Carroll (1979), sempre funcionará como norteadora de comportamentos interna e externamente às organizações. No

Revista de Negócios, v. 23, n. 4, p. 47-69, October, 2018. 
entanto, cabe a elas avaliar se esta responsabilidade deve ser excludente ou complementar à "responsabilidade discricionária", e, desta forma, definir o equilíbrio do grau de "saliência de stakeholder", rumo a uma gestão sócio responsável.

\section{Considerações finais}

O atual modelo de crescimento econômico que norteia a economia de mercado em quase todo o mundo tem proporcionado diversos benefícios, como a produção de bens e serviços e geração de empregos, entretanto cabe salientar que alguns malefícios também são oriundos deste modelo, tais como a miséria, a desigualdade social e a poluição do meio ambiente. Este fato culminou em diversos movimentos sociais buscando defender os interesses da sociedade e reivindicando a integração do tripé do desenvolvimento sustentável (econômico, social e ambiental) por parte das organizações no mundo todo e, neste sentido, surge o conceito de responsabilidade social. Mesmo que a demanda por ações de cunho sócio responsável seja evidente, não são todas as organizações que tem capacidade de colocá-las em prática e, quando o assunto são as empresas familiares, esta realidade é ainda mais distante. Com isso, este trabalho se propôs a fazer um mapeamento das ações de responsabilidade social articuladas por empresas familiares atuantes no agronegócio e, para consecução deste objetivo geral, foram elencados alguns objetivos específicos a serem discutidos a seguir.

$\mathrm{O}$ presente estudo deixou evidente que o principal motivador para que as empresas invistam em ações de cunho socioambiental é a obrigatoriedade legal em detrimento de ações sociais de caráter voluntário (evidenciado pelo índice de saliência de stakeholders), revelando uma atuação reativa e não proativa destas. Carroll (1979), ao discutir as responsabilidades inerentes às organizações, reforçava que aspectos econômicos e legais também são responsabilidades relevantes e que devem ser cumpridas, no entanto não devem ser excludentes às responsabilidades discricionárias, as quais a maioria das empresas analisadas, mostrou ignorar. Por outro lado, Friedman (1984), com uma visão neoliberal, reforça que a obrigatoriedade legal deve ser a única obrigação social da empresa, ao passo em que o enfoque em ações e projetos sociais poderia culminar em perda de competitividade no mercado.

A opção por seguir uma linha de pensamento neoliberal ou social é exclusiva dos gestores, no entanto, é de fundamental importância que todos na organização, desde a presidência até o chão de fábrica, tenham consciência da relevância da responsabilidade social e das obrigações ambientais e saibam como geri-las da forma mais correta e transparente possível junto aos stakeholders.

\section{Implicações e pesquisas adicionais}

Pesquisas adicionais sobre este tópico devem enfocar as interligações entre RSE e aspectos ambientais com maior aprofundamento. É necessário buscar o desenvolvimento de um estudo holístico, para entender os vínculos entre os processos de cada eixo teórico e promover esforços com enfoque na organização. Além disso, seria importante estudar como os stakeholders poderiam estar mais envolvidos no processo de geração e seleção das categorias de análise. Eles podem exercer um papel importante como participantes ativos em diferentes fases do processo, auxiliando na coleta de dados, avaliação de desempenho e refinamento metodológico.

A avaliação qualitativa realizada nesta pesquisa permitiu traçar o perfil pragmático de alguns entraves da SER, em que a maioria deles ainda não foi respondida teoricamente na literatura. Portanto, a necessidade de novos estudos em RSE e aspectos ambientais, para efetivamente avaliar e relatar novos resultados de maneira progressiva, são cruciais para amadurecer proposições futuras sobre o tema. Há limitações associadas a esse tipo de avaliação qualitativa, e essas limitações devem ser consideradas no uso dos resultados obtidos e na obtenção das conclusões. No entanto, uma vez que uma nova lacuna teórica se revela, a visão particular do estudo é claramente assumida como uma visão específica de um tópico específico de pesquisa, onde algumas vertentes se diferem. No entanto isso não deve ser considerado uma restrição importante, e sim, uma abordagem complementar. Isso pode ajudar a promover um debate construtivo em torno dos possíveis caminhos da RSE nas empresas.

\section{Referências}

Revista de Negócios, v. 23, n. 4, p. 47-69, October, 2018. 
Aaker, D., Kumar, V., Day, G. (2004). Pesquisa de Marketing. 2. ed. São Paulo: Atlas.

Agle, B. R., Mitchell, R. K., Sonnenfeld, J. A. (1999). Who matters to CEOs? An investigation of stakeholder attributes and salience, corporate performance, and CEO values. Academy of Management Journal, Briarcliff Manor, 42 (5), 507-525.

Alves, L. E. S. (2001). Governança e cidadania empresarial. Revista de Administração de Empresas, 4 (4), 78-86.

Alves, G. J. S.; Raphaelli, N.; Fangueiro, R. (2006). Desenvolvimento sustentável na indústria têxtil: Estudo de propriedades e características de malhas produzidas com fibras biodegradáveis. In: Congresso Nacional De Técnicos Têxteis, 12.; Fenatêxtil, Recife. Anais... Recife: ABTT.

Araújo, M. R. M. (2006). Exclusão social e responsabilidade social empresarial. Psicologia em Estudo, 11 (2), 417-426.

Arrow, K. J., Dasgupta, P., Goulder, L. H., Mumford, K., Oleson, K. (2012). Sustainability and the measurement of wealth. Environment and Development Economics, 17 (3), 317-353.

Bateman, T. S., \& Snell, S. A. (2006). Administração: Novo cenário competitivo. 2. ed. São Paulo: Atlas.

Becker, H. S. The Epistemology of qualitative Research. (1996). In: Jessor, R., Colby, A.; Shweder, R. A. (Eds.). Ethnography and Human Development. Chicago: University of Chicago Press.

Bendixen, M., \& Abratt, R. (2007). Corporate identity, ethics and reputation in supplier-buyer relationships. Journal of Business Ethics, 76 (1), 69-82.

Boaventura, J. M. G. (2012). Dominância de stakeholders em empresas brasileiras: Contribuições à teoria dos stakeholders. $117 \mathrm{f}$. Tese (Livre Docência em Administração) Faculdade de Economia, Administração e Contabilidade, Universidade de São Paulo, São Paulo.

Borges, A. F., \& Lescura, C. (2010). Aspectos metodológicos da pesquisa sobre empresas familiares no Brasil. In: Encontro de Estudos sobre Empreendedorismo e Gestão de Pequenas
Empresas - EGEPE, 6., 2010, Recife. Anais... Recife: ANEGEPE.

Borges, A. F., Lescura, C., Oliveira, J. L. (2012). O campo de pesquisas sobre empresas familiares no Brasil: Análise da produção científica no período 1997-2009. Organizações \& Sociedade, 19 (61), 315-332.

Bueno, L. F., \& Siggers, R. (2007). Rede de valor. In: CES/FGV-EAESP; AMCE Negócios Sustentáveis. Fóruns empresariais: Sustentabilidade e responsabilidade corporativa. São Paulo: AMCE, pp. 115-122.

Carrigan, M. (1995). Positive and negative aspects of the societal marketing concept: Stakeholder conflicts for the tobacco industry. Journal of Marketing Management, 11 (5), 469485.

Carroll, A. B. (1979). A three-dimensional conceptual model of corporate social performance. Academy of Management Review, 4 (4), 497-505.

Carvalho, L. C., \& Veríssimo, P. (2018). Do empreendedorismo social à responsabilidade social corporativa: um estudo de caso. Holos, 34 (7), 5976.

Casillas, J. C., \& Moreno-Menéndez, A. M. (2014). Speed of the Internationalization Process: The Role of Diversity and Depth in Experiential Learning. Journal of International Business Studies, 45 (1), 85-101.

Chetty, S., \& Agndal, H. (2008). Role of InterOrganizational Networks and Interpersonal Networks in an Industrial District. Regional Studies 42 (2), 175- 187.

Coelho, M. F., \& Gosling, M. (2012).

Competitividade e responsabilidade social corporativa na hotelaria. In: XXXVI Encontro DA ANPAD, Rio de Janeiro. Anais... Rio de Janeiro: EnANPAD.

Costa, R. (2002). A contribuição da ciência contábil para a preservação do meio ambiente. Trabalho de Conclusão de Curso. (Graduação). Ciências Contábeis. UFSC, Santa Catarina.

D’amário, E. Q., \& Soranz, R. F. (2014). A aplicação do modelo de saliência de stakeholders em gestores de bancos de varejo. In: Encontro Internacional sobre Gestão Empresarial e Meio Ambiente, São Paulo. Anais... São Paulo: 
ENGEMA, 2014.

Desa, G. (2017). Resource mobilization in international social entrepreneurship: bricolage as a mechanism of institutional transformation. Entrepreneurship Theory and Practice, 34 (4), 727-751.

Dias, R. (2012). Responsabilidade social: Fundamentos e gestão. São Paulo: Atlas.

Domingues, A. R., Lozano, R., Ceulemans, K., Ramos, T. B. (2017). Sustainability reporting in public sector organisations: Exploring the relation between the reporting process and organizational change management for sustainability. Journal of Environmental Management, 192, 292-301.

Donaldson, T., \& Preston, L. E. (1995). The stakeholder theory of the corporation: Concepts, evidence and implications. Academy of Management Review, 20 (1), 65-91.

Fernandez, P. M. S., Jaen, J. M. S., Ortiz, M. D. G. (2018). Non-financial information as a transparency tool. Razon Historica - Revista Hispanoamericana de Historias de las ideas, 40, 116-132.

Farinos, J. M. (2015). Environmental responsibility and corporate social responsibility. VITRUVIO International Journal of Architectural Technology and Sustainability, 1, 87-91.

Flick, U. (2009). Introdução à pesquisa qualitativa. Porto Alegre: Artmed.

Floriani, O. P., \& Rodrigues, L. C. (2000). Sucessão empresarial: Processo sucessório em empresas familiares. In: Encontro De Estudos Sobre Empreendedorismo e Gestão De Pequenas Empresas - EGEPE, 1., 2000, Maringá. Anais... Maringá: ANEGEPE. pp. 299-312.

Freeman, R. E. (1984). Strategic management: A stakeholder approach. Boston: Pitman.

Gomes, D. V. (2006). Educação para o consumo ético e sustentável. Revista Eletrônica do Mestrado em Educação Ambiental, 16, 18-31.

Gomes, K. N. M. (2004). Responsabilidade social nas empresas: uma nova postura empresarial: $\mathrm{O}$ caso CST. In: Instituto ETHOS. Responsabilidade social das empresas: a contribuição das universidades. São Paulo: Editora Peirópolis. pp. 33-73.
Gomes, P. A., Santos, L. M. L., Gomes, J. V. (2005). Responsabilidade social: Análise das dimensões sistêmicas nas pequenas e grandes empresas. Revista Capital Científico do Centro de Ciências Sociais Aplicadas, 3 (1), 77-90.

Gonçalves, A., Desiderio, A., Gutierrez, G. L. (2006). A responsabilidade social das empresas. ORG \& DEMO, 7 (1,2), 135-152.

González, M., Guzmán, A., Pablo, E., Trujillo, M. A. (2019). Is board turnover driven by performance in family firms? Research in International Business and Finance, 48, 169-186.

Handy, C. Para que serve uma empresa? (2005). In: Rodriguez, M. V. R. (Org.) Ética $e$ responsabilidade social nas empresas. Rio de Janeiro: Elsevier. pp. 118-133.

Harrison, J. S., St John, C. H. (1996). Managing and partnering with external stakeholders. Academy of Management Executive, 10 (2), 46-60.

Instituto Ethos. (2013). Indicadores Ethos de responsabilidade social empresarial. São Paulo: Instituto Ethos de Empresas e Responsabilidade Social.

Lee, P. (2008). A review of the theories of corporate social responsibility: Its evolutionary path and the road ahead. International Journal of Management Reviews, 10 (1), 53-73.

Lethbridge, E. (1997). Tendências da empresa familiar no mundo. Revista BNDES, 4 (7), 1-18.

Lydenberg, S. D. (2005). Corporations and the public interest: Guiding the invisible hand. San Francisco: Berrett-Koehler.

Macêdo, L. F. (2006). Responsabilidade social: a atuação de uma organização pública junto aos seus fornecedores. $147 \mathrm{f}$. Dissertação (Mestrado em Administração - Gestão Social do Trabalho) Faculdade de Economia, Administração, Contabilidade e Ciência da Informação e Documentos, Universidade de Brasília, Brasília.

Machado, H. V. (2005). Reflexões sobre concepções de família e empresas familiares. Psicologia em Estudo, 10 (2), 317-323.

Manzini, E. J. (1991). A entrevista na pesquisa social. Didática, 26 e 27, 149-158.

Marins, J. (2002). Elisão tributária e sua regulação. São Paulo: Dialética. 
MARTINS, G. A. Estudo de caso: uma reflexão sobre a aplicabilidade em pesquisas no Brasil.

Revista de Contabilidade e Organizações, v.2, n.2, o.8-18, 2000.

Medina, G., Santos, A. M. (2017). Curbing enthusiasm for Brazilian agribusiness: The use of actor-specific assessments to transform sustainable development on the ground. Applied Geography, 85, 101-112.

Melo Neto, F. P., Froes, C. (1999). Responsabilidade social e cidadania empresarial: A administração do terceiro setor. Rio de Janeiro: Qualitymark.

Ministério Da Agricultura. (2016). Secretaria Especial de Agricultura Familiar e do Desenvolvimento Agrário: Sobre o programa. Retirado http://www.mda.gov.br/sitemda/secretaria/safmais/sobre-o-programa.

Motta, S. L. S., \& Rossi, G. B. (2001). A influência do fator ecológico na decisão de compra de bens de conveniência. Revista de Administração Mackenzie, 2 (2), 109-130.

Müler, E. T., \& Beuren, I. M. (2010). Estrutura formal e práticas da controladoria em empresas familiares brasileiras. Gestão \& Regionalidade, 26 (76), 105-120.

Oliveira, D. P. R. (1999). Empresa familiar: como fortalecer o empreendimento e otimizar o processo sucessório. São Paulo: Atlas.

Passador, C. S. (2002). A responsabilidade social no Brasil: uma questão em andamento. In: Congreso internacional del clad sobre la reforma del estado y de la administración pública, 7., 2002, Lisboa, Portugal. Anais... Lisboa, Portugal, CLAD.

Pereira, L., \& Fendrich, L. J. (2009). Políticas e práticas de responsabilidade social corporativa em empresas do interior de Santa Catarina e do Paraná: Referenciais de sustentabilidade. In: XXXIII Encontro Da Anpad, São Paulo. Anais... São Paulo: ANPAD.

Pronatec - Programa Nacional de Acesso ao Ensino Técnico e Emprego. (2015). O que é o Jovem Aprendiz. 2015.2 Retirado de: http://www.pronatec2015.com/o-que-e-o-jovemaprendiz/.
Richardson, R. (1999). Pesquisa Social: Métodos e técnicas. São Paulo: Atlas.

Samara, G., \& Paul, K. (2018). Justice versus fairness in the family business workplace: A socioemotional wealth approach. Business Ethics: a European Review, 28 (2), p.175-184.

Sanches, C. S. (2000). Gestão ambiental proativa. RAE - Revista de Administração de Empresas, 40 (1), 76-87.

Serpa, D. A. F. (2006). Efeitos da responsabilidade social corporativa na percepção do consumidor sobre preço e valor: Um estudo experimental. 191 f. Tese (Doutorado em Administração) - Instituto COPPEAD de Administração, Universidade Federal do Rio de Janeiro, Rio de Janeiro.

Serpa, D. A. F., \& Fourneau, L. F. (2007). Responsabilidade social corporativa: uma investigação sobre a percepção do consumidor. Revista de Administração Contemporânea, 11 (3), 83-103.

SESI - Serviço Social da Indústria. (2014). "Meu Novo Mundo" está no ar. Retirado de: http://www.sesisp.org.br/noticias/site-do-projetomeu-novo-mundo-esta-no-ar.

Sousa, A. C. C. (2006). Responsabilidade social e desenvolvimento sustentável: A incorporações do conceito à estratégia empresarial. $203 \mathrm{f}$. Dissertação (Mestrando em Ciências em Planejamento Energético) - Coppe, Universidade Federal do Rio de Janeiro, Rio de Janeiro.

Souza, M. J. B., \& Ferreira, E. (2010). Responsabilidade social em organizações turísticas. In: Philippi Jr., A., Ruschmann, D. M. (Eds.). Gestão ambiental e sustentabilidade no turismo. Barueri: Manole, pp. 755-773.

Stoner, J., \& Freeman, R. E. (1985). Administração. 5. ed. Rio de Janeiro: Prince-Hall do Brasil.

Teodósio, A. S. S., Barbieri, J. C., Csillag, J. M. (2006). Sustentabilidade e competitividade: Novas fronteiras a partir da gestão ambiental. Revistas Gerenciais, 5 (1), 37-49.

Thurow, L. (1997). O futuro do capitalismo: Como as forças econômicas moldam o mundo do amanhã. Rio de Janeiro: Rocco.

Werner, R. (2004). Família e negócios: Um caminho para o sucesso. São Paulo: Manole. 
Venkatraman, S., \& Venkatraman, R. (2019). Communities of Practice Approach for Knowledge Management Systems. Systems, 6 (4), 36.

Yin, R. K. (2005). Estudo de caso: Planejamento e métodos. 3. ed. Porto Alegre: Bookman Companhia.

Zaccariotto, C. C., Chiarinotti, F., Carvalho, L. S. (2015). Fases da Responsabilidade Social Corporativa (RSC): A Evolução do Conceito de RSC. Caderno Profissional de Administração UNIMEP, 5 (2), 103-118.

Zahra, S. A., \& George, G. (2002). International Entrepreneurship: The Current Status of the Field and Future Research Agenda. In: Strategic Entrepreneurship: Creating a New Mindset. (Eds.) M. A. Hitt, R. D. Hisrich, M. Camp, and D. L. Sexton. Malden, MA: Blackwell, pp. 255- 288.

Zhou, L., Wu, W., Luo, X. (2007). Internationalization and the Performance of BornGlobal SMEs: The Mediating Role of Social Networks. Journal of International Business Studies 38 (4), 673-690. 